\title{
Demographic, socio-economic and other associated risk factors for self-medication behaviour among university students of Sri Lanka: a cross sectional study
}

Nirma Subashini ${ }^{1}$ and Lahiru Udayanga ${ }^{2^{*}}$

\begin{abstract}
Background: Self-prescribing practices are considered as a significant issue in the health sector due to malpractices. This has become a more worsen issue in developing countries with easy access to medication. Current study was undertaken to estimate the prevalence of self-medication and to evaluate the driving factors behind this behavior, among university students of Sri Lanka.

Method: A total of 700 randomly selected undergraduates of three state universities in Sri Lanka, were recruited as the study population for the cross-sectional study. Information on socio-demographic, Knowledge, Attitudes and Practices relevant to Self-Medication (SM) were gathered using an interviewer administered questionnaire. Binary logistic regression was used to calculate the Odds Ratios (OR) and the 95\% confidence intervals of the OR for sociodemographic risk factors on SM.

Results: Around 78\% of the studied population denoted a SM behaviour. Only, 37.7\% of respondents were familiar with the classification of "Over the Counter" (OTC) drugs, while majority were well aware of the risks of SM (> 50\%). Fever (61.3\%) and cough (56.7\%) were the major health issues for SM, while antipyretics and drugs for cough and runny nose (73.6\%) were the mostly used medication. Previous experience (76\%) and trivial nature of health issues (73\%) were recognized as the major reasons for SM. Majority of respondents declared that community pharmacies (86.9\%) and left over medication from previous prescriptions (51\%) were the sources for SM. Based on the binary logistic regression, age, residence locality, field of study and academic year were recognized as significant risk factors $(P<0.05)$ for SM within the studied undergraduate population.

Conclusion: Based on the high prevalence rate of SM, the health authorities of Sri Lanka should pay more attention towards the wellbeing and responsible medication usage of undergraduates. Designing of effective tools and regulations to monitor the selling of medication and improving the health education are recommended to ensure responsible SM within the country.
\end{abstract}

Keywords: Self-medication, Knowledge attitudes and practices, Risk factors, Undergraduates, Sri Lanka

\footnotetext{
* Correspondence: udayangaln@gmail.com

${ }^{2}$ Department of Biosystems Engineering, Faculty of Agriculture \& Plantation

Management, Makadura, Wayamba University of Sri Lanka, Gonawila, Sri

Lanka

Full list of author information is available at the end of the article
}

C C The Author(s). 2020 Open Access This article is licensed under a Creative Commons Attribution 4.0 International License, which permits use, sharing, adaptation, distribution and reproduction in any medium or format, as long as you give appropriate credit to the original author(s) and the source, provide a link to the Creative Commons licence, and indicate if changes were made. The images or other third party material in this article are included in the article's Creative Commons licence, unless indicated otherwise in a credit line to the material. If material is not included in the article's Creative Commons licence and your intended use is not permitted by statutory regulation or exceeds the permitted use, you will need to obtain permission directly from the copyright holder. To view a copy of this licence, visit http://creativecommons.org/licenses/by/4.0/. The Creative Commons Public Domain Dedication waiver (http://creativecommons.org/publicdomain/zero/1.0/) applies to the data made available in this article, unless otherwise stated in a credit line to the data. 


\section{Background}

Use of medications for treating themselves, has remained as a common inherent tendency of humans since the initiation of great civilizations. People, belonging to different tribes/civilizations, have practiced selfcare measures to maintain their own health through Self-Medication (SM). This involves quick and direct admittance to treatment in relieving minor ailments $[1,2]$. SM refers to the use of nonprescription medicines (including herbal/traditional products and Over the Counter[OTC] drugs) to treat self-recognized minor ailments, without any consultation of a medical practitioner [2]. Obtaining medication without a prescription, sharing medications with others, or utilizing a medication that is already available in the residence (including leftovers from previous prescriptions)come under SM $[1,3]$.

The patterns of medication is an important health indicator, which reflect the prevalence of diseases and the degree of therapeutic resource utilization within a community [4]. Therefore, SM is often used as a significant indicator in evaluating the effectiveness of the health sector [1, 4, 5]. If done appropriately, the responsible form of SM can save time for the consultation of the medical practitioner and address the limitations in availability of medical practitioners [2, 6, 7]. Further, it may be economical against minor ailments as well as for acute conditions at an urgent situation [7, 8]. Despite, allowing the patients/consumer to play an active role in his/her own care [9], inappropriate form of SM is a major constraint in ensuring the safe and effective use of essential medicines $[4,5]$. Expansions in the availability of pharmaceuticals, in terms of quantities and varieties, at the global scale has resulted easy accessibility for people leading to elevated rates of misusing medicines [10]. This in turn leads to health risks and cause severe economic burdens to governments, while influencing the affordability of medicine by the patients [9-11]. Antibiotic resistance, treatment failures, drug toxicities, adverse drug reactions and prolonged suffering are some of the significant adverse effects of inappropriate use of medicine through SM [6-9]. It may also lead to increased dependency on drugs and deterioration in health status, due to delays in seeking medical advice, when needed $[4,9,11]$.

Increasing rates of antibiotic resistance has become the most serious issue arising due to inappropriate use of antibiotics in SM [12]. According to the World Health Organization (WHO), sub-optimal prescribing practices such as inadequate dosing, incomplete treatment courses and indiscriminate drug use arising due to SM have contributed to the emergence and spread of antimicrobial resistance and emergence of multi-drug resistant pathogens $[10,13]$. Therefore, absurd use of antibiotics and other medicines could directly lead to wastage of medical resources, while challenging the safe and efficacious use of medicines [14-16].

Consequently, there is a growing concern on the illogical use of medicines among the professionals, resulted due to the increase in SM at the global scenario [17]. The prevalence of SM has been estimated to be inbetween 10.3 to $87.0 \%$ worldwide. A rate of $68 \%$ is reported in the European region, while developing countries tend to report further elevated rates of SM that may reach up to $92 \%[9,16,18]$.Higher rates of SM have been reported among the university students in regional countries such as Bangladesh, Pakistan and Saudi Arabia, mostly due to academic competition and pressure [6, 19-22]. Despite elevated prevalence of SM, the overall knowledge of patients and common public on the potential risks of SM remains to be poor, even with prescribed medication for chronic conditions [4, 9]. Majority tend to engage in SM practices solely due to the perceived benefits such as quick relief, for economic benefits, to save time, lack of availability of healthcare personnel and to avoid public embarrassment $[2,4,5,22]$. On the contrary, less attention is paid towards potential side-effects of SM [4], making SM a serious health concern in many countries.

Recent studies have suggested that the misuse of nonprescription drugs amongst adolescents is growing alarmingly. The high involvement of the present day youth with media and internet has increased their exposure to advertising on pharmaceuticals, thereby motivating them towards SM $[18,23]$. According to few recent studies conducted in Jordan [24] and Saudi Arabia [25, 26], medical websites and television or radio advertisements may play a notable role as knowledge sources of SM among undergraduates. On the other hand, a notable fraction of the youth community will be future health care providers, whose own health care seeking behavior would influence their future medical practices [18]. This has raised critical concerns on incorrect selfdiagnosis, drug interaction, and drug usage other than for the original indication [23]. Neglectful regulatory systems in developing countries often tend to contribute towards high prevalence rates of SM [20]. Meanwhile, strict regulations on usage of medicines have suppressed illogical use of SM [14, 27, 28]. Furthermore, drugs that essentially require prescriptions for purchase in developed countries are often available as OTC in developing countries, elevating the potential risk of SM on the health sector [29]. Thus, many developing countries have become ideal breeding grounds for drug-resistance and drug addictions, due to poor supervision of prescriptions [30].

Accordingly, SM has become a common practice in many of the Asian countries including Sri Lanka. Available studies in Sri Lanka has revealed that, majority of 
common diseases such as cold (68.2\%), sore throat $(52.7 \%)$ and fever $(31.0 \%)$ are being treated through SM. Previous prescriptions for similar symptoms or pharmacists opinion towards the illness have been found to be the driving factors for such behaviours [31-33]. SM is recognized to be influenced by a variety of demographic (education level, economic power, family background, knowledge and attitudes on SM), cultural (religious beliefs) and country specific (existing regulations, nature of the health care system and market policies on medication etc.) factors $[5,12,34$, 35]. Evaluation of the potential risk factors that motivate a society towards $\mathrm{SM}$, is of immense importance in guiding the policy makers to control ill effects of SM in developing countries [36].

Despite the critical importance of self-prescribing practices for the health and well-beingof the communities in developing countries, limited focus has been paid to investigate the prevalence of SM. Further, the critical risk factors influencing SM in Sri Lanka remain poorly investigated. Most of the previous studies have only concentrated on the SM practices among athletes, maternal and selected urban populations within Sri Lanka. Meanwhile, SM practices among the university student communities that has become a priority area at the global context remains poorly studied [37, 38]. Therefore, the current study was conducted to evaluate the knowledge, attitudes/perceptions and behaviors/practices on SM and to characterize the critical risk factors influencing the SM behaviour among adolescent undergraduates in the university system of Sri Lanka.

\section{Method}

\section{Selection of study population}

An analytical cross-sectional survey was conducted from February to April 2019.A total of700 randomly selected undergraduates of three state universities in Sri Lanka, namely University of Moratuwa, University of Kelaniya and Wayamba University of Sri Lanka, were recruited as the study population by following Krejcie and Morgan [39]. During the calculation of sample size, it was assumed that the marginal error is $3.5 \%$, population proportion is 0.5 , while the actual population size of the whole undergraduate community per year is 30,000 . During the fieldwork, the sample size was increased to reach 700 undergraduates. Any student who refused to participate in the study due to one or more reasons such as religious beliefs or an opinion that it is not worth participating, were not considered for the survey. New members were recruited, randomly to cater for such exclusions. The selection of students was done in such a way to ensure effective representation of different streams of study and levels of undergraduates.

\section{Data collection}

The socio-economic, Knowledge, Attitudes and Practices (KAPs) of the selected undergraduates on selfmedication behavior were collected using an interviewer-administered questionnaire prepared in three local languages (Sinhala, English and Tamil). The selected undergraduates were interviewed by a group of 5 trained interviewers.

The questionnaire covered the following areas: 1.Socio-demographic information (age, gender, nature of the residence locality, field of study and the level of study of the undergraduates); 2.Self-medication and associated practices (practicing of SM, frequency of SM, maximum number of medications used at once, symptoms for which SM is practiced); 3.Knowledgeon SM (knowledge on Over the Counter Drugs (OTC) and the possible risks of SM); 4 Attitudes towards SM (Reasons for SM, factors considered during selection of medication, Preferred sources of information and medication purchase). Prepared questionnaire was pre-tested and validated by using a preliminary sample of 30 undergraduates.

\section{Data interpretation and statistical analysis}

All collected data were double-checked and verified on the same day for completeness and consistency, prior entering into Microsoft Access ${ }^{\circ}$ data sheets (Version, 2013). Quality controlling procedures were followed throughout the process by trained personnel. Meanwhile the accuracy of data were routinely checked by cross tabulations and logical checks. Discrepant data were checked against original data forms and any mistakes were promptly corrected. The binary logistic regression approach was used to calculate the Odds Ratio (OR) and the 95\% Confidence Intervals (CI) of the OR for sociodemographic risk factors on SM. All statistical analysis were done using the SPSS package 23.

\section{Results \\ Demographic and socio-economic factors}

Among the 700 respondents, majority (55.1\%) were males, while the age group of 24 to 26 years dominated accounting for $54.9 \%$ of the study population. In case of locality, a relatively higher portion of respondents (41.5\%) were residing in semi-urban areas followed by urban (32.1\%) and rural (26.4\%) areas. All the respondents had diverse fields of study, where majority studied agriculture and food sciences (30.3\%), followed by biological sciences (16.3\%) and technology stream (15.1\%). Meanwhile, fourth year undergraduates dominated within the study population (29.1\%), while first year undergraduates denoted the least frequency of $20.6 \%$ (Table 1). 
Table 1 Demographic and socio-economic factors of the study population

\begin{tabular}{llll}
\hline Parameter & & \multicolumn{2}{l}{ Total respondents } \\
\cline { 3 - 4 } & & $\mathrm{n}$ & $\%$ \\
\hline Gender & Male & 386 & 55.1 \\
& Female & 314 & 44.9 \\
(Years) & $20-23$ & 280 & 40.0 \\
& $24-26$ & 384 & 54.9 \\
Locality & $>26$ & 36 & 5.1 \\
& Rural & 185 & 26.4 \\
& Semi-Urban & 290 & 41.5 \\
Field of study & Urban & 225 & 32.1 \\
& Agriculture \& Food Sciences & 212 & 30.3 \\
& Technology & 106 & 15.1 \\
& Biological Sciences & 114 & 16.3 \\
& Commerce and Management & 76 & 10.9 \\
& Physical and Applied Sciences & 92 & 13.1 \\
& Arts & 100 & 14.3 \\
& First year & 144 & 20.6 \\
& Second year & 170 & 24.3 \\
& Third year & 182 & 26.0 \\
& Fourth year & 204 & 29.1 \\
\hline & & & \\
& & &
\end{tabular}

\section{Knowledge on self-medication (SM)}

Of the respondents, $62.3 \%$ were not aware of the classification of OTC medications, which can be purchased without any prescription. Meanwhile $86.0 \%$ were knowing what antibiotics are. Surprisingly, only $54.9 \%$ of the study population correctly mentioned that antibiotics are used against bacterial infections, while a considerable fraction of undergraduates had a limited knowledge on this (45.1\%). Relatively higher percentage of undergraduates were well aware that humans can become resistant to antibiotics (65.9\%) and the possible side effects of strong medications (76.4\%). Around $77 \%$ of the respondents knew that prior knowledge on the mechanism of drugs is necessary before initiating SM practices. However, a notable fraction was not aware of the facts such as higher doses not always result fast recovery (35\%), low doses can't always prevent less adverse conditions (22\%) and medication can't be stopped when basic symptoms fade away (21\%).

Limited knowledge in medicine (64.0\%), risk of having adverse reactions/effects (60.4\%), risk of misdiagnosing (53.7\%) and misuse of drugs/medications (49.6\%) were recognized as the major risks associated with SM. The proportion of respondents aware of possible risks such as the development of drug/medication dependence and administration of medications wrongly (wrong doses and inappropriate methods etc.) were relatively low (24.3 and
$27.1 \%$, respectively). Even though, only a limited faction of study population $(9.1 \%)$ was knowing the chemical composition of drugs used by them, approximately quarter of the respondents (26.3\%) were capable of fully understanding the instructions that comes with medication. Meanwhile, $54.7 \%$ of respondents were proficient in partially understanding the instructions (Table 2).

\section{Practices on self-medication (SM)}

Of the entire study population, 546 undergraduates (78.0\%) practiced SM. Majority (47.1\%) of the undergraduates were practicing SM more than 5 times per year, followed by once in every two three months (31.1\%). Only, $2.3 \%$ of the respondents were frequently indicating SM practices at a weekly interval (Table 3). Approximately $52.9 \%$ of the respondents were using a single drug at a time, while the proportion of undergraduates that used multiple drugs were least (18.9\%). Among the respondents, only $63.3 \%$ were occasionally changing the administrated dose of SM. Interestingly, $21.3 \%$ were never changing the initial dosage. On the other hand, $15.4 \%$ were always changing the administrated dosage of medication. Unsatisfaction of the administering dosage to cure the disease (36.7\%), worsening of the existing condition (23.9\%) and improving of the existing condition (21.1\%) were the major reasons for changing the dosage during SM.

Fever, was the major cause for practicing SM (61.3\%) followed by cough, gastritis and stomachache $(56.7,46.4$ and $42.4 \%$, respectively). Interestingly, complications in eyes $(0.6 \%)$ and ears (2\%) were the least contributing causes for SM within the study population. Antipyretics for fever (73.6\%), drugs for cough/runny nose (73.6\%), pain killers (53.1\%) and Cetrazine (47.4\%) were the most consumed medications used for Self-Medication by the undergraduates (Table 3). On the contrary, other medications such as traditional medicines, Ayurvedic products, primary wound care medication (0.6\%) and sleeping pills (2\%) were the least used medications by the respondents.

Checking the package (69.3\%) and consulting a pharmacist $(60 \%)$ were the most practiced methods of dose determination during SM. Among them, only $12.7 \%$ undergraduates were consulting a medical officer for accurate instructions. Interestingly, $29.3 \%$ of the respondents were always checking the instructions of the medicines that they consume, while $44.0 \%$ were checking the instructions occasionally. Meanwhile, a notably high fraction (26.7\%) were never inspecting the safety instructions for drug usage. A total of 483 undergraduates (69\%) of the study population were keeping the left overs of previously used medications at home, which could be a contributing factor for SM (Table 3). Approximately $29.3 \%$ of the respondents accepted that they might have 
Table 2 Knowledge of the study population on medical drugs and Self-Medication

\begin{tabular}{|c|c|c|c|}
\hline \multirow[t]{2}{*}{ Parameter } & & \multicolumn{2}{|c|}{$\begin{array}{l}\text { Total } \\
\text { respondents }\end{array}$} \\
\hline & & $n$ & $\%$ \\
\hline \multirow[t]{2}{*}{ Familiarity with the classification of OTC } & Yes & 264 & 37.7 \\
\hline & No & 436 & 62.3 \\
\hline \multirow[t]{2}{*}{ Do you know what antibiotics are? } & Yes & 602 & 86.0 \\
\hline & No & 98 & 14.0 \\
\hline \multirow[t]{3}{*}{ Antibiotics are used for? } & Virus infections & 313 & 44.7 \\
\hline & Bacterial infections & 384 & 54.9 \\
\hline & Other & 3 & 0.4 \\
\hline \multirow[t]{7}{*}{ Risks associated with Self-Medication are? } & Risk of using wrong drugs & 347 & 49.6 \\
\hline & Lack of knowledge about medicines & 448 & 64.0 \\
\hline & Risk of having adverse effects & 423 & 60.4 \\
\hline & Risk of misdiagnosing & 376 & 53.7 \\
\hline & Administrating medications wrongly & 260 & 27.1 \\
\hline & Risk of drug dependence & 170 & 24.3 \\
\hline & Other & 10 & 1.4 \\
\hline \multirow{6}{*}{$\begin{array}{l}\text { Which of the following statement(s) about antibiotics } \\
\text { is (are) correct? }\end{array}$} & Higher doses always result fast recovery & 245 & 35.0 \\
\hline & Low doses can always result less adverse conditions & 154 & 22.0 \\
\hline & Switching drugs always enhance drug effect & 52 & 7.4 \\
\hline & Switching drugs always reduce adverse reactions & 40 & 5.7 \\
\hline & $\begin{array}{l}\text { A prior knowledge on the mechanism of drugs is necessary before } \\
\text { initiating self-medication practices }\end{array}$ & 539 & 77.0 \\
\hline & Medication can be stopped when basic symptoms fade away & 147 & 21.0 \\
\hline \multirow[t]{2}{*}{ Can humans become resistant to antibiotics? } & Yes & 461 & 65.9 \\
\hline & No & 239 & 34.1 \\
\hline \multirow[t]{2}{*}{ Can Self-Medication cause side effects? } & Yes & 535 & 76.4 \\
\hline & No & 165 & 23.6 \\
\hline \multirow{2}{*}{$\begin{array}{l}\text { Do you know the chemical composition of the } \\
\text { drugs that you are using? }\end{array}$} & Yes & 64 & 9.1 \\
\hline & No & 636 & 90.9 \\
\hline \multirow{3}{*}{$\begin{array}{l}\text { Level of understanding of the instructions used for } \\
\text { Self-Medication }\end{array}$} & Fully understood & 184 & 26.3 \\
\hline & Partially understood & 383 & 54.7 \\
\hline & Did not understand & 133 & 19.0 \\
\hline
\end{tabular}

taken the same medication with different brand names at the same time. Meanwhile $40.1 \%$ stated that they have faced adverse impacts of SM. Consulting the pharmacy staff $(45.4 \%)$ and family member/friend (39.1\%) were the mostly practiced response for such adverse reactions (Table 3).

\section{Attitudes on self-medication (SM)}

Previous experience (76.0\%), trivial nature of issues (73.0\%)and necessity of avoiding embarrassing moments (52.6\%) were the major contributing factors that encouraged the respondents for SM. Meanwhile, time, urgency and economic constraints were having limited influences
(23.0, 22.7 and $17.4 \%$, respectively) on SM behaviour. A higher proportion of the study population (40.7\%) were satisfied with any medication provided by the pharmacist. Interestingly, a notable percentage of respondents were paying attention to the possible side effects (32.1\%), brand name $(31.7 \%)$ and price $(25.7 \%)$, when purchasing drugs or medication. Community pharmacies (86.9\%) and left over from previous prescriptions (51\%) were the most preferred sources of obtaining medications. On the contrary, friends (21.1\%) and neighbours (4.1\%) were the least preferred sources (Table 4).

Own previous experience $(77.9 \%)$ was the most preferred source of advice for selection of medications, 
Table 3 Practices of the study population related to Self-Medication

\begin{tabular}{|c|c|c|c|}
\hline \multirow[t]{2}{*}{ Parameter } & & \multicolumn{2}{|c|}{$\begin{array}{l}\text { Total } \\
\text { respondents }\end{array}$} \\
\hline & & $\mathrm{n}$ & $\%$ \\
\hline \multirow[t]{2}{*}{ Practicing of Self-Medication } & Yes & 546 & 78.0 \\
\hline & No & 154 & 22.0 \\
\hline \multirow[t]{5}{*}{ Frequency of Self-Medication } & Once a week & 16 & 2.3 \\
\hline & Every $2-3$ weeks & 48 & 6.9 \\
\hline & Once a month & 88 & 12.6 \\
\hline & Every two three months & 218 & 31.1 \\
\hline & More than 5 times per year & 330 & 47.1 \\
\hline \multirow[t]{3}{*}{ Number of medicines simultaneously used } & 1 & 370 & 52.9 \\
\hline & 2 & 198 & 28.3 \\
\hline & Multiple & 132 & 18.9 \\
\hline \multirow[t]{3}{*}{ How often do you change the dosage? } & Always & 108 & 15.4 \\
\hline & Occasionally & 443 & 63.3 \\
\hline & Never & 149 & 21.3 \\
\hline \multirow[t]{4}{*}{ Reasons for changing the dosage } & Improving conditions & 148 & 21.1 \\
\hline & Worsening conditions & 167 & 23.9 \\
\hline & To reduce adverse conditions & 128 & 18.3 \\
\hline & Felt insufficient to cure the cause & 257 & 36.7 \\
\hline \multirow[t]{11}{*}{ Symptoms for Self Medication } & Cough & 397 & 56.7 \\
\hline & Stomachache & 297 & 42.4 \\
\hline & Fever & 429 & 61.3 \\
\hline & Skin wounds/symptoms & 157 & 22.4 \\
\hline & Allergies & 97 & 13.9 \\
\hline & Eye symptoms & 4 & 0.6 \\
\hline & Ear symptoms & 14 & 2.0 \\
\hline & Diarrhea & 58 & 8.3 \\
\hline & Back pain relief & 112 & 16.0 \\
\hline & gastritis & 325 & 46.4 \\
\hline & Other (Specify) & 122 & 17.4 \\
\hline \multirow[t]{13}{*}{ Common drugs (medicines) used } & Antipyretics for fever: Paracetamol & 515 & 73.6 \\
\hline & Pain killers: Paracetamol, Panadine, Aspirin, Brufen & 372 & 53.1 \\
\hline & $\begin{array}{l}\text { Drugs for cough/runny nose: Cough syrups, piriton, } \\
\text { cetirizine }\end{array}$ & 515 & 73.6 \\
\hline & Laxatives: Lactulose & 19 & 2.7 \\
\hline & $\begin{array}{l}\text { Vitamins: Vitamin C, Vitamin E, Vitamin B, Iron, Folic } \\
\text { acid, Calcium }\end{array}$ & 283 & 40.4 \\
\hline & Antiallergic: Fexofenadine, Prednisolon, Piriton & 126 & 18.0 \\
\hline & Sleeping pills & 14 & 2.0 \\
\hline & Antibiotics: amoxicillin, cloxacillin & 272 & 38.8 \\
\hline & Pain relief balms: Diclofenac gel & 301 & 43.0 \\
\hline & Inhalers & 50 & 7.1 \\
\hline & Cetrazine & 332 & 47.4 \\
\hline & Drugs for gastritis & 290 & 41.4 \\
\hline & Anti-itching balms: Lactocalamine, hydrocortisone & 165 & 23.6 \\
\hline
\end{tabular}


Table 3 Practices of the study population related to Self-Medication (Continued)

\begin{tabular}{|c|c|c|c|}
\hline \multirow[t]{2}{*}{ Parameter } & & \multicolumn{2}{|c|}{$\begin{array}{l}\text { Total } \\
\text { respondents }\end{array}$} \\
\hline & & $n$ & $\%$ \\
\hline & Diarreha: Jeevani & 101 & 14.4 \\
\hline & Other & 4 & 0.6 \\
\hline \multirow[t]{6}{*}{ Determining the dose } & Checking the package & 485 & 69.3 \\
\hline & Consulting a pharmacist & 420 & 60.0 \\
\hline & Consulting family members/friends & 265 & 37.9 \\
\hline & From my previous experience & 369 & 52.7 \\
\hline & By guessing the dosage & 33 & 4.7 \\
\hline & Consulting a medical officer & 89 & 12.7 \\
\hline \multirow[t]{3}{*}{ How often do you check the instructions for drug usage? } & Always & 205 & 29.3 \\
\hline & Occasionally & 308 & 44.0 \\
\hline & Never & 187 & 26.7 \\
\hline \multirow[t]{2}{*}{ Do you keep old medicine/left overs at your home? } & Yes & 483 & 69 \\
\hline & No & 217 & 31 \\
\hline \multirow{2}{*}{$\begin{array}{l}\text { Have you ever found out that you had taken the same drug with different } \\
\text { names at the same time? }\end{array}$} & Yes & 205 & 29.3 \\
\hline & No & 485 & 69.3 \\
\hline \multirow[t]{2}{*}{ Have you faced any side effects due to Self-Medication? } & Yes & 281 & 40.1 \\
\hline & No & 419 & 59.9 \\
\hline \multirow[t]{5}{*}{ What did you do when side effects arise due to Self-Medication? } & Switch to another drug & 58 & 8.3 \\
\hline & Consulted pharmacy staff & 318 & 45.4 \\
\hline & Consult family member/friend & 107 & 39.1 \\
\hline & Consulted a physician & 46 & 6.6 \\
\hline & Other (specify) & 4 & 0.6 \\
\hline
\end{tabular}

followed by a previous prescription of a doctor (68.6\%), pharmacist advice (47.9\%) and opinion of a family member (45.4\%). It was interesting to note that internet and social media accounted for around $36.7 \%$ preference among the undergraduates as a source of information. A majority of respondents believed that they have not consumed any counterfeit drugs (79.6\%). At the same time, higher percentage of respondents $(53.7 \%)$ were not sure whether common disease conditions can be cured by SM. On the contrary, only $46.7 \%$ believed that common diseases can be successfully treated via SM. Interestingly, a notable fraction of undergraduates (43.6\%) were willing to recommend medicines for their friends or family members, which could promote SM (Table 4).

\section{Risk factors for self-medication}

As suggested by the results of binary logistic regression, all the basic demographic and socio-economic factors (except for gender) were having a significant association with the practicing of SM by the studied population (Table 5). Even though, males were having a relatively higher preference for $\mathrm{SM}(P=0.08 ; \mathrm{OR}=1.65 ; \mathrm{CI}=$ 0.92-2.01) than the females, the association of gender and SM behavior was non-significant. The highest prevalence of SM was observed among the students belonging to the age group of $24-26$ years $(81.3 \%$; OR = $1.23)$, followed by $20-23(77.9 \%$; OR $=1)$. Students from urban $(92.4 \%$; OR $=10.18 ; \mathrm{CI}=8.20-10.75)$ and semiurban $(81.7 \%$; OR $=3.72 ; \mathrm{CI}=2.60-4.13)$ areas had significantly higher tendency $(P=0.004)$ for SM behaviour, than those from rural localities (54.6\%). Interestingly, undergraduates from Biological Sciences (94.7\%; OR = 2.08; $\quad \mathrm{CI}=1.46-3.02)$ showed a significantly higher prevalence of SM, followed by undergraduates from Agriculture \& Food Sciences $(89.6 \%$; OR $=1)$. In case of academic year of study, the final (fourth) year undergraduates denoted the highest prevalence of SM (97.1\%; $\mathrm{OR}=23.57 ; \mathrm{CI}=20.88-24.45)$, followed by third year undergraduates $(85.7 \%$; $\mathrm{OR}=4.29$; $\mathrm{CI}=3.05-4.82)$. The tendency for practicing SM significantly increased with the academic year $(P<0.001)$ as shown in Table 5 .

\section{Discussion}

\section{Practices on SM}

SM is an important aspect, which should be rigorously monitored by the health authorities (especially in 
Table 4 Attitudes of the study population on Self-Medication

\begin{tabular}{|c|c|c|c|}
\hline \multirow[t]{2}{*}{ Parameter } & & \multicolumn{2}{|c|}{ Total respondents } \\
\hline & & $\%$ & $\mathrm{n}$ \\
\hline \multirow[t]{8}{*}{ Reasons for Self-Medication } & Previous experience & 532 & 76.0 \\
\hline & Problem too trivial (minor) & 511 & 73.0 \\
\hline & Urgency of the problem & 159 & 22.7 \\
\hline & No time to go for a doctor & 161 & 23.0 \\
\hline & Consulting a doctor is too expensive & 122 & 17.4 \\
\hline & Quick relief & 279 & 39.9 \\
\hline & To avoid the embarrassing moments & 368 & 52.6 \\
\hline & Other (specify) & 3 & 0.4 \\
\hline \multirow[t]{5}{*}{ Considerations during purchase } & Type of the drug & 89 & 12.7 \\
\hline & Brand name & 222 & 31.7 \\
\hline & Price & 180 & 25.7 \\
\hline & Side effects & 225 & 32.1 \\
\hline & Anything given by the pharmacist & 285 & 40.7 \\
\hline \multirow[t]{5}{*}{ Preferred sources of medication purchase } & Community pharmacies & 608 & 86.9 \\
\hline & Left over from previous prescriptions & 357 & 51.0 \\
\hline & Family members & 250 & 35.7 \\
\hline & From friends & 148 & 21.1 \\
\hline & Neighbours & 29 & 4.1 \\
\hline \multirow[t]{8}{*}{ Preferred sources of information for Self-Medication } & Previous doctor's prescription & 480 & 68.6 \\
\hline & Opinion of a friend & 240 & 34.3 \\
\hline & Own previous experience & 545 & 77.9 \\
\hline & Pharmacist advise & 335 & 47.9 \\
\hline & Opinion of family member & 318 & 45.4 \\
\hline & Advertisements/Leaflets & 79 & 11.3 \\
\hline & Internet and social media & 257 & 36.7 \\
\hline & Other (Specify) & 0 & 0.0 \\
\hline \multirow[t]{2}{*}{ Do you believe that you might have taken counterfeit drugs? } & Yes & 143 & 20.4 \\
\hline & No & 557 & 79.6 \\
\hline \multirow[t]{3}{*}{ Can common diseases be successfully treated through Self-Medication? } & Yes I can & 324 & 46.7 \\
\hline & Not sure & 308 & 44.0 \\
\hline & No, I cannot & 68 & 9.7 \\
\hline \multirow[t]{2}{*}{ Do you recommend drugs (medicines) for others? } & Yes & 305 & 43.6 \\
\hline & No & 395 & 56.4 \\
\hline
\end{tabular}

developing countries) to ensure safe and responsible usage of drugs by patients. This requires effort to aware the patients with adequate information regarding the usage of pharmaceuticals and instances to consult a qualified medical officer, when needed [24, 40, 41]. The undergraduate population in the current study reported a $78 \%$ prevalence of SM at higher SM frequencies such as $2-3$ times per month or more (52.9\%). Several studies conducted in Oman (94\%), Palestine (98\%), India (87\%), Pakistan (76\%)also have reported similarly high levels of SM among undergraduates $[18,23,42-44]$. On the contrary, Buke et al. [37] has reported only a $45 \%$ prevalence of SM among university students in Turkey. Meanwhile a Brazilian study conducted with university healthcare and non-healthcare students has shown $57.7 \%$ prevalence of SM [45]. Findings of the current study stands in line with few similar studies conducted with university students in Pakistan [22], Slovenia [46] and Palestine [18].

Ear and eye related issues were the least dealt issues through SM, mostly due to the higher sensitivity of those systems. Antipyretics (such as Panadol, Paracetamol), 
Table 5 Results of the binary logistic regression

\begin{tabular}{|c|c|c|c|c|c|c|c|c|}
\hline \multirow[t]{2}{*}{ Parameter } & & \multicolumn{2}{|c|}{ Total respondents } & \multicolumn{2}{|c|}{ Prevalence of SM behaviour } & \multirow[t]{2}{*}{$P$ value } & \multirow{2}{*}{$\begin{array}{l}\text { Odds } \\
\text { Ratio }\end{array}$} & \multirow{2}{*}{$\begin{array}{l}95 \% \\
\text { Confidence } \\
\text { Interval for } \\
\text { the Odds } \\
\text { ratio } \\
\text { Number }\end{array}$} \\
\hline & & $n$ & $\%$ & $\mathrm{n}$ & $\%$ & & & \\
\hline \multirow[t]{2}{*}{ Gender } & Female & 314 & 44.9 & 230 & 73.2 & \multirow[t]{2}{*}{0.081} & Reference & \\
\hline & Male & 386 & 55.1 & 316 & 81.9 & & 1.65 & $0.92-2.01$ \\
\hline \multirow{3}{*}{$\begin{array}{l}\text { Age } \\
\text { (Years) }\end{array}$} & $20-23$ & 280 & 40.0 & 218.0 & 77.9 & \multirow[t]{3}{*}{0.001} & Reference & \\
\hline & $24-26$ & 384 & 54.9 & 312.0 & 81.3 & & 1.23 & $1.05-1.61$ \\
\hline & $>26$ & 36 & 5.1 & 16.0 & 44.4 & & 0.23 & $0.12-0.74$ \\
\hline \multirow[t]{3}{*}{ Locality } & Rural & 185 & 26.4 & 101.0 & 54.6 & \multirow[t]{3}{*}{0.004} & Reference & \\
\hline & Semi-Urban & 290 & 41.4 & 237.0 & 81.7 & & 3.72 & $2.60-4.13$ \\
\hline & Urban & 225 & 32.1 & 208.0 & 92.4 & & 10.18 & $8.20-10.75$ \\
\hline \multirow[t]{6}{*}{ Field of study } & Agriculture \& Food Sciences & 212 & 30.3 & 190.0 & 89.62 & \multirow[t]{6}{*}{$<0.001$} & Reference & \\
\hline & Arts & 100 & 14.3 & 41.0 & 41.00 & & 0.08 & $0.03-0.68$ \\
\hline & Biological Sciences & 114 & 16.3 & 108.0 & 94.74 & & 2.08 & $1.46-3.02$ \\
\hline & Commerce and Management & 76 & 10.9 & 52.0 & 68.42 & & 0.25 & $0.13-0.71$ \\
\hline & Physical and Applied Sciences & 92 & 13.1 & 70.0 & 76.09 & & 0.37 & $0.22-0.97$ \\
\hline & Technology & 106 & 15.1 & 85.0 & 80.19 & & 0.47 & $0.27-0.94$ \\
\hline \multirow[t]{4}{*}{ Year of study } & First year & 144 & 20.6 & 84.0 & 58.3 & \multirow[t]{4}{*}{$<0.001$} & Reference & \\
\hline & Second year & 170 & 24.3 & 108.0 & 63.5 & & 1.24 & $1.06-1.70$ \\
\hline & Third year & 182 & 26.0 & 156.0 & 85.7 & & 4.29 & $3.05-4.82$ \\
\hline & Fourth year & 204 & 29.1 & 198.0 & 97.1 & & 23.57 & $20.88-24.45$ \\
\hline
\end{tabular}

drugs for cough/runny nose (cough syrups, piriton, cetirizine) and pain killers (Paracetamol, Panadine, Aspirin and Brufen) were the mostly used medication that denoted a usage by more than $50 \%$ of the studied population. Several recent studies have reported similar findings, where painkillers, flu/cough remedies have emerged as most commonly used medication in SM [2, 5, 8, 17, 32, 45]. Especially, few studies that focused on the SM behaviours of undergraduate populations in Bangladesh [21] and Jordan [24] have also reported a similar observation in the region. Even though, a higher usage level of antibiotics have been reported in many previous studies [12,17], only $38.8 \%$ of the entire study population administrated antibiotics during SM. A similar rate of antibiotic usage has been found among medical and non-medical students in Jordan [24].

\section{Knowledge on SM}

Despite the high rates of SM, only approximately one third of the entire study population $(37.7 \%)$ was familiar with the classification of OTC drugs. This suggested that SM is practiced with limited knowledge. Further, only $53.3 \%$ of the study population were truly aware of the fact that antibiotics are used against bacterial infections, among $86 \%$ who claimed to have knowledge on antibiotics. A notable fraction of the study population carried misconceptions on antibiotics such as higher doses always result fast recovery (35\%), low doses can always result less adverse conditions (22\%) and administration of antibiotics can be stopped immediately when basic symptoms fade away (21\%). A recent study conducted by Grigoryan et al. has also reported that people in Southern and Eastern European countries tend to possess a less accurate knowledge on antibiotics, especially regarding the effectiveness of antibiotics against bacterial and viral infections [38]. However, majority $(65.9 \%)$ of the respondents were aware of antibiotic resistance and the ability of SM causing ill effects (76.4\%). This level of understanding within undergraduates of Sri Lanka remains higher than in Europe (48\%), while lies closer $(73 \%)$ to the awareness level in United States [38, 47]. A recent study conducted in Turkey has also reported that a high proportion of undergraduates tend to engage in SM, since they only know that SM is wrong and is capable of causing ill effects [37]. Regardless of this primary understanding, more awareness on the devastating ill effects of SM should be communicated to the undergraduates to promote responsible SM within Sri Lanka. Few recent studies that have focused on the undergraduate communities in several regional countries 
have also recommended such measures to enhance the responsible SM [7, 21, 24, 26].

High SM prevalence within the studied university population, despite the reasonable knowledge on the risks of SM such as risk of using wrong drugs (49.6\%), lack of knowledge about medicines (64\%), risk of having adverse effects (60.4\%) and risk of misdiagnosis (53.7\%), agrees with the findings of previous studies [4, 24, 48]. This has been described as a phenomenon, whereby the practitioners of SM tend to outweigh the potential risks of side-effects with potential benefits, due to their belief that only safe medicines are permitted to be sold as OTC $[17,48]$. Further, the limited understanding on the classification of OTC and malpractices of pharmacists (who sell non-OTC medication without proper prescriptions) could also be prominent risk factors for SM prevalence [12, 23, 24].

\section{Attitudes on SM}

The risk of SM behavior among the studied Sri Lankan university population further increased since the preferred methods to determine the administration dosage of medication were checking the package, consulting a pharmacist or based on previous experience. Therefore, administration of appropriate doses remains questionable as majority of the respondents claimed that they are capable of understanding the instructions that comes with the package, partially $(54.7 \%)$ or very poorly $(19 \%)$. A recent study in China has also reported a similar low level of understanding the instructions that comes with medication among the university students [17]. Majority of students changed the administration dosage occasionally $(63.3 \%)$ or never changed the dosage $(21.3 \%)$, which could result severe side effects in case of misdiagnosis or due to over use $[2,12]$. Irrational use of antibiotics arising due to inappropriate antibiotic prescribing, selection of wrong drug, dosage and inappropriate period of use could lead to serious health concerns and antibiotic resistance $[12,49,50]$.

More than one third of the study population have faced side effects of SM previously and stop taking the drug $(76 \%)$ or consulting a pharmacist $(45.4 \%)$ has remained as their preferred option. Meanwhile only a limited number of respondents tend to consult a physician in such occasions. This behavior could also worsen the risk of SM on the well-being of the community, due to poor treatment seeking behavior [12, 24]. Previous experience, trivial nature of the problem, need for avoiding the embarrassing moments and quick relief have been the major reasons for SM among the studied university student population. These findings agree with many previous studies on SM conducted among different populations [2, 20-26, 51]. Even though, majority of the respondents were accepting any medication provided by the pharmacist, a notable fraction were considering the potential side effects and the brand name they preferred in purchasing medication. A study conducted in Saudi Arabia has reported that majority $(84.1 \%)$ pay attention to the effectiveness of medications, followed by the brand [51].

Community pharmacies (86.9\%) was the most preferred source of medication purchase for SM followed by left over from previous prescriptions and family members. Community pharmacies often remain as the most preferred source of medication and other therapeutic drugs in many studies conducted all over the world [12, 20, 24, 40, 52, 53]. Availability of left-over medication or home pharmacies could provide free access and easy visualization of medication, which in turn act as promoters of SM [2, 20, 54]. As emphasized by Reynolds and McKee left over medication from previous prescriptions suggest that either doctors over-prescribe and/or the patients not complying with the prescription [55].

Own previous experience (77.9\%), previous prescriptions of a doctor (68.6\%), pharmacist advice (47.9\%) and opinions of family members $(45.4 \%)$ were used for the decision making in SM in the current study. Several previous studies have also reported similar findings $[2,18$, $20-24,44,56]$. Both family members and the pharmacists often tend have inadequate knowledge about antibiotics $[2,40,56]$. Further, previous prescriptions may not be ideal for the current scenario, elevating the risk for unintended side effects due to SM. Continuous use of the same medicines (based on previous prescriptions) could lead to development of drug resistance, addition and concealing of malicious and potentially fatal diseases $[17,57-59]$. In addition, following of an advice of a family member in selecting medication would evidence for culturally inherited acceptance of self-medication [40, $55,56]$, which remain as a critical risk factor.

Majority of respondents believed that common diseases could be successfully treated through SM, which remains as a crucial factor to be considered by the health authorities in the country $[7,8,24]$. Further, nearly half of the respondents $(43.6 \%)$, accepted that they are recommending drugs for their friends and other family members, which is a serious concern. On the contrary, a recent study conducted in Brazil and Saudi Arabia have reported that a notable fraction of university students tend to discourage SM practices among their friends and relatives $[2,20]$.

\section{Risk factors for SM}

Even though males were having a higher tendency for $\mathrm{SM}(\mathrm{OR}=1.65)$ in comparison to female undergraduates, the effect of gender on SM behavior was found to be insignificant. This finding agrees with several previous 
studies conducted in India [7], Lithuania [12] and western China [40], while an opposite trend has been reported from Brazil [2].Few recent studies conducted in Bangladesh [21] and Saudi Arabia [25] also reported that the effect of gender on SM remained insignificant among undergraduates. Age was also a significant risk factor, where younger students showed a higher prevalence rate of SM, which agrees with several other studies $[2,17,38]$. Students from urban and semi-urban localities denoted significantly higher prevalence rates of SM, suggesting that locality is a critical risk factor. Undergraduates from such areas have more exposure to medical services and media, which directly encourage them for SM $[18,23]$. Further, the availability of community pharmacies is also high in such areas, unlike in rural areas, which could have resulted the above observation [23]. On the contrary, an opposite trend has been reported in Lithuania, where rural people have shown the high prevalence of SM behaviour [12].

Undergraduates from science background (biological sciences and agriculture \& food sciences) denoted higher SM bahaviours than undergraduates from art or commerce fields. Undergraduates with a science background may have a better knowledge on medication, leading to elevated SM rates than undergraduates from nonscience backgrounds [24, 26]. Academic year of study also emerged as a significant risk factor, where final year students (third year and fourth year) had higher prevalence rates of SM. However, a previous study conducted in Sri Lanka has reported a similar positive trend among the academic year of students and the SM behaviour of undergraduates in the University of Peradeniya, which was not statically significant [32]. Few regional studies conducted in Pakistan [19] and Saudi Arabia [26] have evidenced that SM practices have increased with the academic year in undergraduate populations. An opposite trend has been reported in Brazil, where final year students have shown lesser SM preference, which has also remained non-significant [2]. Similar reluctance in SM has been shown by a cohort of pharmacy and medicine undergraduates in Saudi Arabia with the progression in educational career [20]. However, the influence of friends, more exposure to media and advertisements, availability of left-over medication may be the influencing factors for the higher SM practice among final year students in the current study. Several studies conducted in the region have evidenced that both medical websites and advertisements play a key role in inducing the SM behaviour within undergraduates [20, 21, 24-26].

The current study has evaluated the SM behaviour of undergraduates belonging to three major state universities of Sri Lanka, out of 15 government universities in Sri Lanka, which remains as a limitation. However, a satisfactory proportion of undergraduate community has been recruited from three major universities representing all the academic fields to compensate for this limitation. Further, a recall bias could occur as the SM practices were reported by the students, which remains a general limitation in this type of studies [40]. In addition, the chronic diseases, which are often associated with $\mathrm{SM}$, were not assessed within the study. However, this also has been mentioned as a limitation in similar studies [2].

Findings of the current study suggest a higher prevalence of SM among the undergraduate community in Sri Lanka, which should be considered as a critical factor in health care management. Despite strict national regulations that prohibits issue of medication without proper prescriptions, findings of this study suggests easy access to medications and therapeutic drugs in Sri Lanka from community pharmacies and other sources without supervision of a physician. Numerous countries have reported similar situations $[8,12,24,52]$, emphasizing the need for more effective supervision system and tools to regulate selling of antibiotics and other medication [24]. As highlighted by the WHO, responsible SM could reduce costs and economic burden of healthcare systems and individual citizens [60]. This requires proper knowledge and transparent regulatory system to ensure responsible use of medication and therapeutic drugs via SM $[20,24]$. Therefore, properly planned health education programmes, effective tools and regulations are recommended to be implemented within Sri Lanka, to empower Sri Lankans to make well informed decisions regarding SM. Especially, such educational programmes should be combined into the general curricular of the university system of Sri Lanka, to promote responsible SM within the community.

\section{Conclusions}

In conclusion, the findings of the current study denoted a $78 \%$ prevalence rate of SM among the studied undergraduate population, which is notably high. Approximately $52.9 \%$ of the respondents were using a single drug at a time, while $63.3 \%$ were occasionally changing the administrated dose of SM. Antipyretics for fever (73.6\%), drugs for cough/runny nose (73.6\%), pain killers (53.1\%) and Cetrazine (47.4\%) were the most consumed medications used for SM by the undergraduates. The knowledge level of undergraduates on OTC medication remained limited, while community pharmacies were found to play a major role in promoting irresponsible SM. This highlights the potential risk of undergraduate population in Sri Lanka to face ill effects of SM. Locality of students, age, field of study and the year of study were recognized as the significant risk factors associated with the SM behavior among the undergraduate students. Therefore, the health authorities of Sri Lanka should pay 
more attention towards health education and regulations for responsible medication selling within the country, so that the wellbeing of the community could be assured through responsible SM. Further, designing of effective tools and regulations to monitor the selling of medication at the community pharmacies, and improving the knowledge and attitudes of pharmacists are also recommended to promote responsible SM within the country.

\section{Abbreviations}

Cl: Confidence Intervals; KAPs: Knowledge, Attitudes and Practices; OTC: Over the Counter; OR: Odds Ratio; SM: Self-Medication; WHO: World Health Organization

\section{Acknowledgements}

All the undergraduates who participated the study are acknowledged for their cooperation during the data collection.

\section{Authors' contributions}

NR-Collection of data and writing the manuscript; LU-Conceptualization of the study, collection of data, statistical analysis and writing the manuscript. All authors read and approved the final manuscript.

\section{Funding}

No funding was received.

\section{Availability of data and materials}

The datasets used and/or analyzed during the current study are available from the corresponding author on reasonable request.

\section{Ethics approval and consent to participate}

Ethical approval was obtained from the Ethics Review Committee of the Faculty of Agriculture \& Plantation Management, Wayamba University of Sri Lanka. The confidentiality of the acquired data was maintained throughout the study. The written consent of the participants was acquired to participate in the study prior to the conducting of socio-economic survey.

\section{Consent for publication}

Not Applicable.

\section{Competing interests}

The authors have declared that they have no competing interests.

\section{Author details}

${ }^{1}$ Department of Horticulture \& Landscape Gardening, Faculty of Agriculture \& Plantation Management, Makadura, Wayamba University of Sri Lanka, Gonawila, Sri Lanka. Department of Biosystems Engineering, Faculty of Agriculture \& Plantation Management, Makadura, Wayamba University of Sri Lanka, Gonawila, Sri Lanka.

Received: 20 August 2019 Accepted: 31 March 2020

Published online: 04 May 2020

\section{References}

1. Dukes MN, World Health Organization. Drug utilization studies: methods and uses: World Health Organization. Copenhagen: Regional Office for Europe; 1993.

2. da Silva MG, Soares MC, Muccillo-Baisch AL. Self-medication in university students from the city of Rio Grande, Brazil. BMC Public Health. 2012;12(1): 339.

3. Du Y, Knopf H. Self-medication among children and adolescents in Germany: results of the National Health Survey for children and adolescents (KiGGS). Br J Clin Pharmacol. 2009;68(4):599-608.

4. Hughes L, Whittlesea C, Luscombe D. Patients' knowledge and perceptions of the side-effects of OTC medication. J Clin Pharm Ther. 2002;27(4):243-8.

5. James H, Handu SS, Al Khaja KA, Otoom S, Sequeira RP. Evaluation of the knowledge, attitude and practice of self-medication among first-year medical students. Med Princ Pract. 2006;15(4):270-5.
6. Al Rasheed F, Naqvi AA, Ahmad R, Ahmad N. Academic stress and prevalence of stress-related self-medication among undergraduate female students of health and non-health cluster colleges of a public sector university in Dammam, Saudi Arabia. J Pharm Bioallied Sci. 2017;9(4):251.

7. Selvaraj K, Kumar SG, Ramalingam A. Prevalence of self-medication practices and its associated factors in urban Puducherry, India. Perspect Clin Res. 2014;5(1):32.

8. Parulekar M, Mekoth N, Ramesh CM, Parulekar A. Self-medication in developing countries a systematic review. J Pharm Technol Res Manage. 2016;4(2):103-27.

9. Albatti TH, Alawwad S, Aldueb R, Alhoqail R, Almutairi R. The self medication use among adolescents aged between 13-18 years old; Prevalence and behavior, Riyadh-Kingdom of Saudi Arabia, from 20142015. Int J Pediatr Adolesc Med. 2017:4(1):19-25.

10. Ali SE, Ibrahim MI, Palaian S. Medication storage and self-medication behaviour amongst female students in Malaysia. Pharm Pract. 2010;8(4): 226-32.

11. Alhomoud F, Aljamea Z, Almahasnah R, Alkhalifah K, Basalelah L, Alhomoud FK. Self-medication and self-prescription with antibiotics in the Middle East-do they really happen? A systematic review of the prevalence, possible reasons, and outcomes. Int J Infect Dis. 2017;1(57):3-12.

12. Pavyde $E$, Veikutis $V$, Mačiulienè $A$, Mačiulis $V$, Petrikonis $K$, Stankevičius E. Public knowledge, beliefs and behavior on antibiotic use and selfmedication in Lithuania. Int J Environ Res Public Health. 2015;12(6):7002-16.

13. World Health Organization. WHO global strategy for containment of antimicrobial resistance. Geneva: World Health Organization; 2001.

14. Morgan DJ, Okeke IN, Laxminarayan R, Perencevich EN, Weisenberg S. Nonprescription antimicrobial use worldwide: a systematic review. Lancet Infect Dis. 2011;11(9):692-701.

15. Bi P, Tong S, Parton KA. Family self-medication and antibiotics abuse for children and juveniles in a Chinese city. Soc Sci Med. 2000;50(10):1445-50.

16. Goossens $H$, Ferech M, Vander Stichele R, Elseviers M, ESAC project group. Outpatient antibiotic use in Europe and association with resistance: a crossnational database study. Lancet. 2005;365(9459):579-87.

17. Pan H, Cui B, Zhang D, Farrar J, Law F, Ba-Thein W. Prior knowledge, older age, and higher allowance are risk factors for self-medication with antibiotics among university students in southern China. PloSOne. 2012;7(7): e41314.

18. Sawalha AF. A descriptive study of self-medication practices among Palestinian medical and nonmedical university students. Res Soc Adm Pharm. 2008;4(2):164-72

19. Abbas A, Ahmed FR, Yousuf R, Khan N, Nisa ZU, Ali SI, Rizvi M, Sabah A, Tanwir S. Prevalence of self-medication of psychoactive stimulants and antidepressants among undergraduate pharmacy students in twelve Pakistani cities. Trop J Pharm Res. 2015;14(3):527-32.

20. Albusalih FA, Naqvi AA, Ahmad R, Ahmad N. Prevalence of self-medication among students of pharmacy and medicine colleges of a public sector university in Dammam City. Saudi Arabia Pharm. 2017;5(3):51.

21. Seam M, Reza O, Bhatta R, Saha BL, Das A, Hossain M, Uddin SM, Karmakar $P$, Choudhuri M, Sattar MM. Assessing the perceptions and practice of selfmedication among Bangladeshi undergraduate pharmacy students. Pharmacy. 2018;6(1):6.

22. Naqvi AA, Ahmad R, Qadeer O, Khan MH, Nadir MN, Alim M. The prevalence of self medication and the factors influencing its practice in pharmacy students of Karachi, Pakistan: A mix mode study. J Young Pharm. 2016;8(3):230.

23. Zafar SN, Syed R, Waqar S, Zubairi AJ, Vaqar T, Shaikh M, Yousaf W, Shahid S, Saleem S. Self-medication amongst university students of Karachi: prevalence, knowledge and attitudes. J Pak Med Assoc. 2008;58(4):214.

24. Alshogran OY, Alzoubi KH, Khabour OF, Farah S. Patterns of self-medication among medical and nonmedical University students in Jordan. Risk Manag Healthcare Policy. 2018;11:169.

25. AlRaddadi KK, Barakeh RM, AlRefaie SM, AlYahya LS, Adosary MA, Alyahya KI. Determinants of self-medication among undergraduate students at King Saud University: knowledge, attitude and practice. J Health Specialties. 2017; 5(2):95.

26. Naqvi AA, Ahmad R, Elewi AA, AlAwa AH, Alasiri MJ. Dietary supplement use among undergraduate male students in health and non-health cluster colleges of a public-sector university in Dammam, Saudi Arabia. BMC Complement Altern Med. 2018;18(1):269.

27. Borg MA, Scicluna EA. Over-the-counter acquisition of antibiotics in the Maltese general population. Int J Antimicrob Agents. 2002;20(4):253-7. 
28. Laxminarayan $\mathrm{R}$, Heymann DL. Challenges of drug resistance in the developing world. BMJ. 2012;344:e1567.

29. Shakoor O, Taylor RB, Behrens RH. Assessment of the incidence of substandard drugs in developing countries. Tropical Med Int Health. 1997; 2(9):839-45

30. Harbarth S, Samore MH. Antimicrobial resistance determinants and future control. Emerg Infect Dis. 2005;11(6):794.

31. Anurasinghe $\mathrm{KM}$, Ravinath $\mathrm{BM}$, Jayawardane $\mathrm{P}$. Use of non-prescription analgesics and its associated factors in Boralasgamuwa medical officer of health area; 2017.

32. Gunawardhana CB, Sakeena MH, Sivayoganthan C. Awareness of rational medication use and antibiotic self-medication practices among undergraduate students in a university in Sri Lanka. Trop J Pharm Res. 2015; 14(4):723-9.

33. Wijesinghe PR, Jayakody RL, de A Seneviratne R. Prevalence and predictors of self-medication in a selected urban and rural district of Sri Lanka. WHO South-East Asia J Public Health. 2012;1(1):28.

34. Montastruc JL, Bagheri H, Geraud T, Lapeyre-Mestre M. Pharmacovigilance of self-medication. Therapie. 1997;52(2):105-10.

35. Habeeb JG, Gearhart JG. Common patient symptoms: patterns of selftreatment and prevention. J Miss State Med Assoc. 1993;34(6):179-81.

36. Paula Martins A, da Costa MA, Mendes Z, Soares MA, Ferreira P, Nogueira A. Self-medication in a Portuguese urban population: a prevalence study. Pharmacoepidemiol Drug Saf. 2002;11(5):409-14.

37. Buke C, Hosgor-Limoncu M, Ermertcan S, Ciceklioglu M, Tuncel M, Köse T, Eren S. Irrational use of antibiotics among university students. J Infect. 2005; 51(2):135-9.

38. Grigoryan L, Burgerhof JG, Degener JE, Deschepper R, Lundborg CS, Monnet DL, Scicluna EA, Birkin J, Haaijer-Ruskamp FM. SAR consortium. Attitudes, beliefs and knowledge concerning antibiotic use and selfmedication: a comparative European study. Pharmacoepidemiol Drug Saf. 2007;16(11):1234-43.

39. Krejcie RV, Morgan DW. Determining sample size for research activities. Educ Psychol Meas. 1970;30:607-10.

40. Lv B, Zhou Z, Xu G, Yang D, Wu L, Shen Q, Jiang M, Wang X, Zhao G, Yang S, Fang Y. Knowledge, attitudes and practices concerning self-medication with antibiotics among university students in Western China. Tropical Med Int Health. 2014;19(7):769-79.

41. World Health Organization. The role of the pharmacist in self-care and selfmedication: report of the 4th WHO consultative group on the role of the pharmacist, the Hague, the Netherlands, 26-28 august 1998. Geneva: World Health Organization; 1998.

42. Hughes CM, McElnay JC, Fleming GF. Benefits and risks of self-medication. Drug Saf. 2001;24(14):1027-37.

43. Al Flaiti M, Al Badi K, Hakami WO, Khan SA. Evaluation of self-medication practices in acute diseases among university students in Oman. J Acute Dis. 2014;3(3):249-52.

44. Verma RK, Mohan L, Pandey M. Evaluation of self-medication among professional students in North India: proper statutory drug control must be implemented. Evaluation. 2010;3(1):60-4.

45. Aquino DS, Barros JA, Silva MD. Self-medication and health academic staff. Ciencia Saude Coletiva. 2010;15(5):2533-8.

46. Klemenc-Ketis Z, Hladnik Z, Kersnik J. Self-medication among healthcare and non-healthcare students at University of Ljubljana, Slovenia. Med Principles Pract. 2010;19(5):395-401

47. Corbett KK, Gonzales R, Leeman-Castillo BA, Flores E, Maselli J, Kafadar K. Appropriate antibiotic use: variation in knowledge and awareness by Hispanic ethnicity and language. Prev Med. 2005;40(2):162-9.

48. Bisell P, Ward PR, Noyce PR. Mapping the contours of risk: consumer perceptions of non-prescription medicines. J Soc Adm Phar. 2000;17(3):136-42.

49. Lu Y, Hernandez $P$, Abegunde D, Edejer T. The world medicines situation 2011. Medicine expenditures. Geneva: World Health Organization; 2011.

50. Maciulaitis $R$, Janusonis T, Petrikaite $V$, Aukstakalniene A. Assessment of antibiotic use and comparison with recommendations for their rational use. Medicina. 2006;42(12):999-1005.

51. Alghadeer S, Aljuaydi K, Babelghaith S, Alhammad A, Alarifi MN. Selfmedication with antibiotics in Saudi Arabia. Saudi Pharm J. 2018:26(5):719-24.

52. Al-Azzam S, Al-Husein B, Alzoubi F, Masadeh M, Ali M. Self-medication with antibiotics in Jordanian population. Int J Occup Med Environ Health. 2007; 20(4):373-80.
53. Muras M, Krajewski J, Nocun M, Godycki-Cwirko M. A survey of patient behaviours and beliefs regarding antibiotic self-medication for respiratory tract infections in Poland. Arch Med Sci. 2013;9:854-7.

54. Stasio MJ, Curry K, Sutton-Skinner KM, Glassman DM. Over-the-counter medication and herbal or dietary supplement use in college: dose frequency and relationship to self-reported distress. J Am Coll Heal. 2008; 56(5):535-48.

55. Reynolds L, McKee M. Factors influencing antibiotic prescribing in China: an exploratory analysis. Health Policy. 2009;90(1):32-6.

56. Abahussain E, Matowe LK, Nicholls PJ. Self-reported medication use among adolescents in Kuwait. Med Princ Pract. 2005:14(3):161-4.

57. Bauchner $\mathrm{H}$, Wise P. Antibiotics without prescription: "bacterial or medical resistance"? Lancet. 2000;355:1480-4.

58. Calabresi P, Cupini LM. Medication-overuse headache: similarities with drug addiction. Trends Pharmacol Sci. 2005:26:62-8.

59. French L, Horton J, Matousek M. Abnormal vaginal discharge: what does and does not work in treating underlying causes. J Fam Pract. 2004:53:805-14

60. World Health Organization. Guidelines for the regulatory assessment of medicinal products for use in self-medication. Geneva: World Health Organization; 2000.

\section{Publisher's Note}

Springer Nature remains neutral with regard to jurisdictional claims in published maps and institutional affiliations.
Ready to submit your research? Choose BMC and benefit from:

- fast, convenient online submission

- thorough peer review by experienced researchers in your field

- rapid publication on acceptance

- support for research data, including large and complex data types

- gold Open Access which fosters wider collaboration and increased citations

- maximum visibility for your research: over $100 \mathrm{M}$ website views per year

At BMC, research is always in progress.

Learn more biomedcentral.com/submissions 